Univerzitet u Beogradu
Poljoprivredni fakultet
Institut za poljoprivrednu tehniku
Naučni časopis
POLJOPRIVREDNA TEHNIKA
Godina XLIII
Broj 1, 2018.
Strane: $1-11$

UDK: 611.792.

Review article

\title{
APPLICATION OF ANAEROBIC ADHESIVES AT MACHINERY REPAIR
}

\author{
Vladimir Bashkirtsev $^{1}$, Yury Kuznetsov ${ }^{* 2}$, Larisa Kalashnikova ${ }^{3}$ \\ ${ }^{I}$ Russian Engineering Academy of Management and Agribusiness, Settlement \\ "Chelyuskinsky" Moscow Region, Russian Federation \\ ${ }^{2}$ Orel State Agrarian University named after N.V. Parakhin, Orel, Russian Federation \\ ${ }^{3}$ Orel State University named after I.S. Turgenev, Orel, Russian Federation
}

\begin{abstract}
The importance of application of anaerobic adhesives during maintenance and repair works is illustrated. The comparative processing characteristics of anaerobic compositions and recommendations on adequate choice of adhesive material trademark are presented. We suggest the conventional technologies of operating capacity restoration of joints and assemblies that lost their performance when in operation with anaerobic adhesives application.
\end{abstract}

Key words: adhesive, anaerobic composition, polymer, repair, restoration, hermetization, fixation, clearance gap.

\section{INTRODUCTION}

At long-term operation of agricultural machinery of different purpose at the places of metal stress concentration, fatigue cracks can appear $[1,2,3]$. As an example, the crack is presented in figure 1 (a) near the central cylinder head bolt of the internal combustion engine. It connects the cooling system cavity and unit head oil duct. This is one of the reasons of getting of engine oil into the engine cooling system. No one of the existing conventional repair technologies with applied welding method is not suitable to fill-in such kind of crack. The repair and technical enterprises experience testifies that such a unit is usually rejected.

\footnotetext{
* Corresponding author. E-mail: kentury@rambler.ru
} 
The usage of polymer materials allows unit performance restoration with the above mentioned defect without dismounting the engine and its complete disassembly. For conducting repair operations, it is reasonable to apply anaerobic adhesives among polymer materials $[4,5]$. Anaerobic adhesives are special liquor mixtures of different viscosity. Name "anaerobic" is taken from biological terminology, where it was applied to microorganisms existing without oxygen. "Anaerobic" means that adhesive material can remain in initial state without its property change for a long time and harden quickly forming solid polymer layer in narrow clearances between surfaces at temperatures 15 $35^{\circ} \mathrm{C}$ in the conditions of terminating the aerial oxygen contact [6].

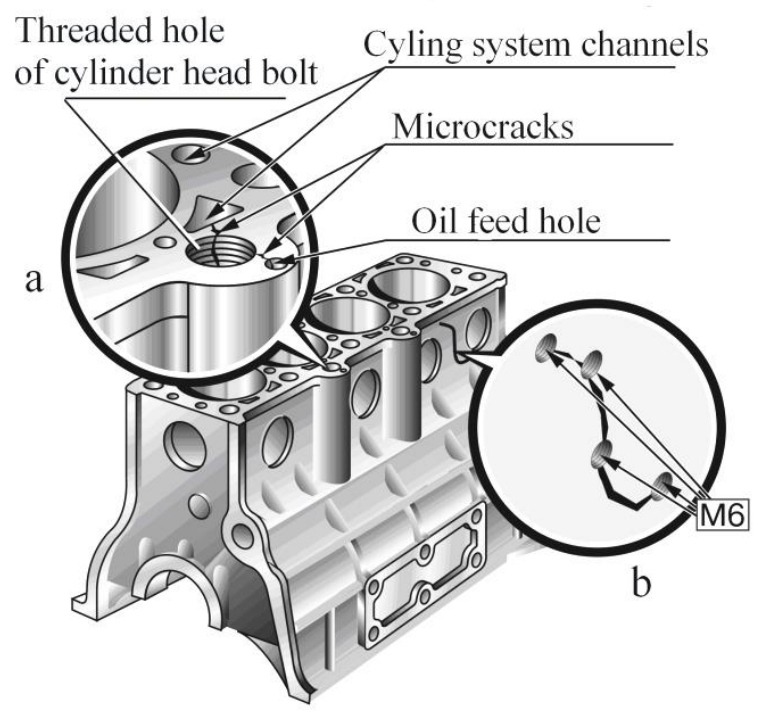

Figure 1. Hermetization of microcracks in engine cylinder block

It should be emphasized, that anaerobic adhesives can be used not only at cracks hermetization. In addition, they can be in demand to fix the tread, rolling bearing fit restoration and can be used as liquid gaskets etc. [4, 7].

Anaerobic composition base is capable for polymerization compounds of acrylic variety, for example, dimethacrylic ester of polyalkyleneglycols. Anaerobic composition consists of inhibitive and initiators providing its long-term storage and rapid curing in clearances and thickeners, modifiers, colorants and other additives, etc. All anaerobic adhesives trademarks are one-component materials.

The advantages of anaerobic adhesives are the following $[4,5,6]$ :

- high rate of hardening, (fixation duration is 15-30 min);

- high viscosity, it allows clearance tightening up to $3 \mathrm{~mm}$ (except for saturating compositions);

- feature stability at long-term operation in conditions of thermal shock and elevated vibration;

- high strength properties (hardness at impact shift is $8-20 \mathrm{~kJ} / \mathrm{m}^{2}$; ultimate share stress - 20-30 MPa). 
Among the main disadvantages of anaerobic compositions, it is possible to differentiate the following:

- low strength at bonding greasy surfaces (ultimate share stress - 0,5-5 MPa);

- dependence of strength properties of hardened adhesive from the clearance between associable surfaces.

The technology of anaerobic adhesive application is sufficiently simple and universal. While performing repair operations these operation is done manually applying adhesive from standard bottle, with special nozzle.

The right choice of adhesive material trademark, technology compliance of adhesive composition application is of significant importance.

\section{MATERIAL AND METHODS}

For the purpose of reasonable choice of anaerobic adhesive trademark while performing maintenance and repair works of different joints, the following anaerobic compositions were analyzed: AH-1У (Russia), Уг-7 (Russia), Анатерм-6к (Russia), Анатерм-111 (Russia), Permatex ${ }^{\circledR}$ Bearing Mount for Close Fits (USA), Permatex ${ }^{\circledR}$ Bearing mount for Worn (USA).

\section{RESULTS AND DISCUSSION}

While selecting anaerobic adhesive trademark it is necessary to take into consideration the operation conditions of the repaired object: its loading mode, temperature mode, clearance between joint surfaces, and surface cleaning quality, coating nature, etc.

One more important parameter is abrasive viscosity. Its choice should be based on clearance between assembled parts (table 1).

Comparative characteristics of some the most commonly used anaerobic adhesives of Russia and the USA production are presented in table 2 [6].

According to strength properties, anaerobic polymer materials are divided into high- middle- and low-strength. After hardening anaerobic materials possess high thermal and chemical resistance, maintain operability of joints and parts at their operation in contact with organic solvents and aggressive media in broad range of temperatures and pressures. The rate of hardening and duration of achievement of maximum strength of connections with anaerobic adhesives depend on ambient temperature. For example, at temperature below $15^{\circ} \mathrm{C}$ polymerization is slowing down. High penetrating capacity of anaerobic adhesives provides heavy coverage of cracks, microdefects of welded joints and clearances.

It is necessary to stress that anaerobic composition-hardening rate is influenced with contacting material. According to this feature, contacting materials can be divided into three groups: steels);

- active - accelerating polymer hardening (cuprum alloys, nickel, low-carbon

- normal - not influencing hardening rate (ferrum, carbon steels, zinc); 
- passive - slowing down hardening (high-carbon steels, aluminum, gold, titanium and its alloys, materials with anticorrosion coatings, plastic articles).

On the open surfaces, anaerobic adhesives can remain liquid for an indefinite time and they are easily removed including water-cleaning solutions.

Table 1. Selection of anaerobic adhesive viscosity depending on tightened clearance

\begin{tabular}{|c|c|c|c|c|c|}
\hline $\begin{array}{c}\text { Clearance, } \\
\text { mm }\end{array}$ & up to 0,07 & up to 0,15 & up to 0,25 & up to 0,35 & up to 0,60 \\
\hline $\begin{array}{c}\text { Adhesive } \\
\text { viscosity, } \\
\text { MPa:s }\end{array}$ & $5-20$ & $100-150$ & $500-800$ & $(1-3) \cdot 10^{3}$ & $(5-35) \cdot 10^{3}$ \\
\hline
\end{tabular}

Table 2. Technological characteristics of some anaerobic adhesives of Russia and the USA production [6]

\begin{tabular}{|c|c|c|c|c|}
\hline Trademark & Color & $\begin{array}{c}\text { Tightened } \\
\text { clearance, } \\
\text { not more than } \\
\text { (thread diameter) }\end{array}$ & $\begin{array}{l}\text { Operating } \\
\text { temperature } \\
\text { range, }{ }^{O} \mathrm{C}\end{array}$ & Producer \\
\hline \multicolumn{5}{|c|}{ Compositions for infirm fixation of thread } \\
\hline Анатерм-17 & blue & $0,35 \mathrm{~mm}$ & $-60 \ldots+150$ & \begin{tabular}{|lll} 
Federal State & \\
Unitary & \\
Enterprise & \\
«Research & \\
Institute & of \\
Polymers» &
\end{tabular} \\
\hline Унигерм-2М & green & $0,15 \mathrm{~mm}$ & $-60 \ldots+150$ & $\begin{array}{lll}\text { Federal State } \\
\text { Unitary } & \\
\text { Enterprise } & \\
\text { «Research } & \\
\text { Institute } & \text { of } \\
\text { Polymers» } & \\
\end{array}$ \\
\hline $\begin{array}{l}\text { Low Strength } \\
\text { Thread lockers }\end{array}$ & purple & $\begin{array}{l}\text { no more } \\
\text { M6 }\end{array}$ & $-54 \ldots+149$ & Permatex (USA) \\
\hline Анагерм-100 & green & $0,3 \mathrm{~mm}$ & $-60 \ldots+150$ & $\begin{array}{c}L L C \\
\text { «ECHNO- } \\
\text { BASIS» }\end{array}$ \\
\hline Анагерм-120 & green & $0,45 \mathrm{~mm}$ & $-60 \ldots+150$ & $\begin{array}{c}L L C \\
\text { «ECHNO- } \\
\text { BASIS» } \\
\end{array}$ \\
\hline \multicolumn{5}{|c|}{ Compositions for middle fixation of thread } \\
\hline $\begin{array}{l}\text { MediumStrength } \\
\text { Threadlockers }\end{array}$ & blue & M6...M20 & $-54 \ldots+149$ & Permatex (USA) \\
\hline Анатерм-18 & blue & $0,4 \mathrm{~mm}$ & $-60 \ldots+100$ & $\begin{array}{c}\text { Federal State } \\
\text { Enterprise } \\
\text { «Research } \\
\text { Institute of } \\
\text { Polymers» }\end{array}$ \\
\hline
\end{tabular}




\begin{tabular}{|c|c|c|c|c|}
\hline Унигерм-6 & red & $0,3 \mathrm{~mm}$ & $-60 \ldots+150$ & $\begin{array}{c}\text { Federal State } \\
\text { Unitary } \\
\text { Enterprise } \\
\text { «Research } \\
\text { Institute of } \\
\text { Polymers» }\end{array}$ \\
\hline Анагерм-101 & green & $0,3 \mathrm{~mm}$ & $-60 \ldots+150$ & $\begin{array}{c}L L C \\
\ll T E C H N O- \\
B A S I S »\end{array}$ \\
\hline LOCTITE-243 & blue & $>M 36$ & $-55 \ldots+150$ & LOCTITE \\
\hline \multicolumn{5}{|c|}{ Compositions for firm fixation of thread } \\
\hline Анагерм-102 & blue & $0,3 \mathrm{~mm}$ & $-60 \ldots+150$ & $\begin{array}{c}L L C \\
\text { «TECHNO- } \\
\text { BASIS» }\end{array}$ \\
\hline $\begin{array}{l}\text { High Strength } \\
\text { Thread locker }\end{array}$ & red & $M 10 \ldots M 20$ & $-54 \ldots+149$ & $\begin{array}{c}\text { Permatex } \\
\text { (USA) }\end{array}$ \\
\hline Анатерм-111 & green & $0,4 \mathrm{~mm}$ & $-60 \ldots+150$ & $\begin{array}{c}\text { Federal State } \\
\text { Unitary } \\
\text { Enterprise } \\
\text { «Research } \\
\text { Institute of } \\
\text { Polymers» }\end{array}$ \\
\hline Унигерм-9 & green & $0,3 \mathrm{~mm}$ & $-60 \ldots+150$ & $\begin{array}{c}\text { Federal State } \\
\text { Unitary } \\
\text { Enterprise } \\
\text { «Research } \\
\text { Institute of } \\
\text { Polymers» }\end{array}$ \\
\hline LOCTITE-270 & green & $>M 20$ & $-55 \ldots+150$ & LOCTITE \\
\hline \multicolumn{5}{|c|}{ Compositions for fixation of bearings, bushes } \\
\hline LOCTITE-603 & green & $0,15 \mathrm{~mm}$ & $-50 \ldots+150$ & LOCTITE \\
\hline LOCTITE-638 & green & $0,25 \mathrm{~mm}$ & $-50 \ldots+150$ & LOCTITE \\
\hline $\begin{array}{l}\text { Bearing mount for } \\
\text { Close Fits }\end{array}$ & green & $0,18 \mathrm{~mm}$ & $-50 \ldots+204$ & $\begin{array}{l}\text { Permatex } \\
\text { (USA) }\end{array}$ \\
\hline $\begin{array}{c}\text { Bearing Mount for } \\
\text { Worn Parts }\end{array}$ & silver & $0,5 \mathrm{~mm}$ & $-54 \ldots+149$ & $\begin{array}{l}\text { Permatex } \\
\text { (USA) }\end{array}$ \\
\hline Анагерм-103ВТ & orange & $0,3 \mathrm{~mm}$ & $\partial o+250$ & $\begin{array}{c}L L C \\
\text { «ECHNO- } \\
B A S I S »\end{array}$ \\
\hline Анагерм-103 & red & $0,4 \mathrm{~mm}$ & $-60 \ldots+150$ & $\begin{array}{c}\text { LLC } \\
\text { «TECHNO- } \\
\text { BASIS» }\end{array}$ \\
\hline Анатерм-6К & red & $0,45 \mathrm{~mm}$ & $-60 \ldots+150$ & $\begin{array}{c}\text { Federal State } \\
\text { Unitary } \\
\text { Enterprise } \\
\text { «Research } \\
\text { Institute of } \\
\text { Polymers» }\end{array}$ \\
\hline
\end{tabular}




\begin{tabular}{|c|c|c|c|c|}
\hline Анатерм-111 & green & $0,4 \mathrm{~mm}$ & $-60 \ldots+150$ & $\begin{array}{c}\text { Federal State } \\
\text { Unitary } \\
\text { Enterprise } \\
\text { «Research } \\
\text { Institute of } \\
\text { Polymers» }\end{array}$ \\
\hline \multicolumn{5}{|c|}{ Compositions for microcracks hermetization } \\
\hline Анагерм-112 & blue & $0,05 \mathrm{~mm}$ & $\partial o+150$ & $\begin{array}{c}L L C \\
\ll T E C H N O- \\
\text { BASIS» }\end{array}$ \\
\hline Анатерм-1y & red & $0,1 \mathrm{~mm}$ & $-50 \ldots+150$ & $\begin{array}{c}\text { Federal State } \\
\text { Unitary } \\
\text { Enterprise } \\
\text { «Research } \\
\text { Institute of } \\
\text { Polymers» }\end{array}$ \\
\hline Унигерм-7 & green & $0,2 \mathrm{~mm}$ & $-50 \ldots+150$ & $\begin{array}{c}\text { Federal State } \\
\text { Unitary } \\
\text { Enterprise } \\
\text { «esearch } \\
\text { Institute of } \\
\text { Polymers» }\end{array}$ \\
\hline \multicolumn{5}{|c|}{ Encapsulating compositions (liquid gaskets) } \\
\hline Анагерм-130 & green & $0,6 \mathrm{~mm}$ & $-60 \ldots+150$ & $\begin{array}{c}L L C \\
« T E C H N O- \\
B A S I S »\end{array}$ \\
\hline Анатерм-501 & red & $0,6 \mathrm{~mm}$ & $-60 \ldots+150$ & $\begin{array}{c}\text { Federal State } \\
\text { Unitary } \\
\text { Enterprise } \\
\text { «Research } \\
\text { Institute of } \\
\text { Polymers» }\end{array}$ \\
\hline $\begin{array}{c}\text { Anaerobic } \\
\text { Flange Sealant }\end{array}$ & red & $0,38 \mathrm{~mm}$ & $-54 \ldots+149$ & Permatex (USA) \\
\hline LOCTITE-577 & yellow & - & $-55 \ldots+150$ & LOCTITE \\
\hline
\end{tabular}

The carried out investigations display high efficiency of application of anaerobic adhesive polymers in their pure form and with application of different fillers allowing to obtain the required adhesive properties [6,7].

For hermetization of cracks in body parts, with wall thickness more than $3 \mathrm{~mm}$ (fig 1(a)) it is rational to use specially developed for these purposes anaerobic sealants of the Russian production. Anaerobic sealants are liquids of different viscosity and which are capable to remain in the initial state without changing properties for a long time and to harden quickly in narrow clearances at temperature $15-35{ }^{\circ} \mathrm{C}$ after terminating the contact with aerial oxygen, with firm polymer layer formation.

These sealants after hardening possess high thermal and chemical resistibility, providing the required operational capability of joints and parts even at their operation in contact with organic solvents, aggressive media at temperature from -50 to $+150{ }^{\circ} \mathrm{C}$. 
Since crack, as a rule, has no constant clearance, repair kit has two adhesive compositions. Composition AH-1y has excessive penetrating capacity and hardens at clearance not less than $0,1 \mathrm{~mm}$. Plymer $У_{\Gamma-7}$ has excessive viscosity and hardens at clearance up to $0,2 \mathrm{~mm}$.

Microcrack hermetization technology is in the following. Crack is ungreased («transfused») with acetone or gazoline, blow off with compressed air and is dried. The item should be set in a way that crack is placed vertically. It is necessary to apply several times from flask sealer of trademark $\mathrm{AH}-1 \mathrm{Y}$ (red) with less viscosity and having excessive penetrating capacity. After an hour exposition at room temperature, the crack is transfused with more viscous sealer $У_{\Gamma-7}$ (green). Duration of sealer setting at room temperature is about 6 hours. Temperature increase reduces the hardening time, and decrease increases alternatively.

If there is an access to a crack as it is presented in fig. 1 (b), then in this case the following hermetization technology can be used. To prevent further crack spreading it is necessary to drill out its ends for thread M6. Then a plug with high impact anaerobic sealer applied on the thread is screwed into the prepared hole. At hermetization of long cracks for better item rigidity and for illumination of displacements between crack fractures, it is possible additionally along the crack to drill some analogical holes for thread, with the following mounting of threaded plugs on high impact sealer. While using different appliances it is possible to fill in vertical and overhead cracks, it allows sealing the crack without car unlocking.

With the help of anaerobic adhesives, it is possible to restore operating capacity of loose rolling bearing fit (fig. 2), in the body as well as on the shaft. Compositions Анатерм-6к and Анатерм-111 (Russia) allow to restore clearances up to $0,27 \mathrm{~mm}$. At this, time of composition setting at room temperature is about 25-30 min, hardening is 5$6 \mathrm{~h}$.

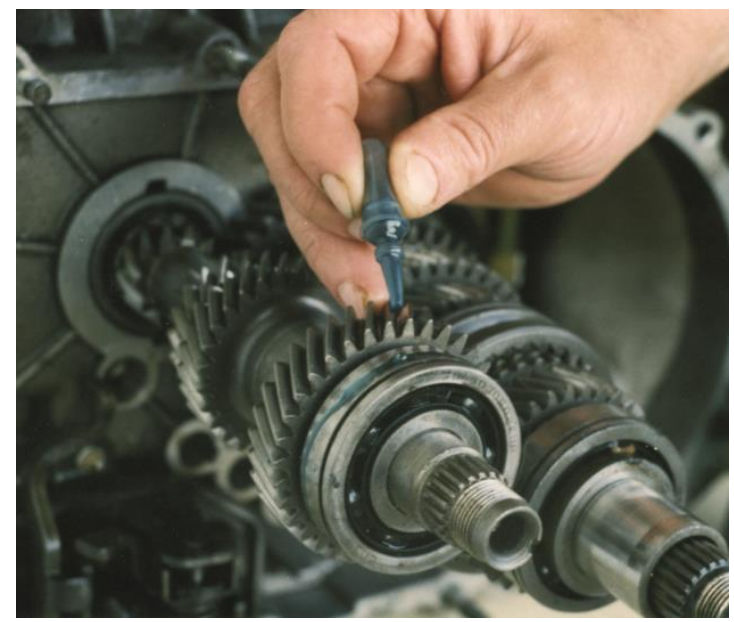

Figure 2. Restoration of rolling bearing fit

Adhesive compositions of the USA production are of a special interest: Permatex® Bearing Mount for Close Fits and Permatex® Bearing mount for Worn. 
Fast setting anaerobic adhesive Permatex ${ }^{\circledR}$ Bearing Mount for Close Fits has low viscosity, which increases fit density. Diametric clearance at the given composition should not exceed 0,13 mm. Cream composition Permatex ${ }^{\circledR}$ Bearing mount for Worn Parts can be used at clearances up to $0,5 \mathrm{~mm}$ per diameter.

While using adhesion compositions a special attention should be paid to the quality of the restorable surface preparation. Before polymer application, the surface is carefully cleaned. It is descaled and derusted mechanically. The surfaces are ungreased with brush or cotton swabs soaked with gasoline or acetone and dried.

Anaerobic composition is applied from flask dropper on the whole outside surface of one of the associable parts and assemble the unit. It is necessary to pay attention that sealer will not get on retainer or bearing tracks.

At great wears, it is necessary to carry out operation on part center adjustment. Herewith it is possible to use centering inserts made of soft sheet metal or soft wire.

At restoration of identical part set, it is advisable to use purpose-made mandrels (fig. 3). For example, to provide bearing adjustment about an axis of shaft rotation is necessary one of the unworn areas of shaft surface should support that mandrel. In this case, bearing that is located in mandrel will be adjusted about shaft rotation axis.

The carried out investigations, displayed that the life of the restored in this way seat for rolling bearing turns out to be higher in comparison with junction without polymer layer. This is explained by the fact that adhesive composition between bearing body and case (shaft) provides more even load distribution between rolling bodies (fig. 4). Herewith more even load distribution between rolling bodies of bearing takes place and contact pressure on the working surfaces of bearing parts decreases. If bearing is set without polymer the loading is concentrated on one rolling body (fig. 5), at that this concentration increases at joint clearance growing, this reduces dramatically bearing life. It should be pointed out that polymer layer protects surfaces from corrosion.

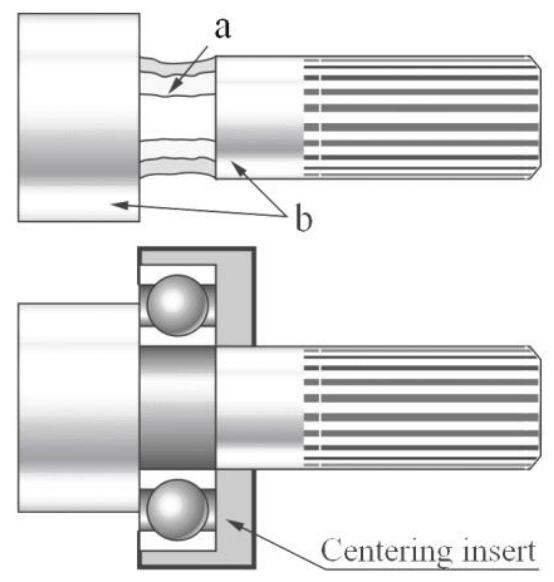

Figure 3. Bearing adjustment about shaft by mandrel: $a$-irregularly worn seat for bearing; $b$ - unworn shaft part 


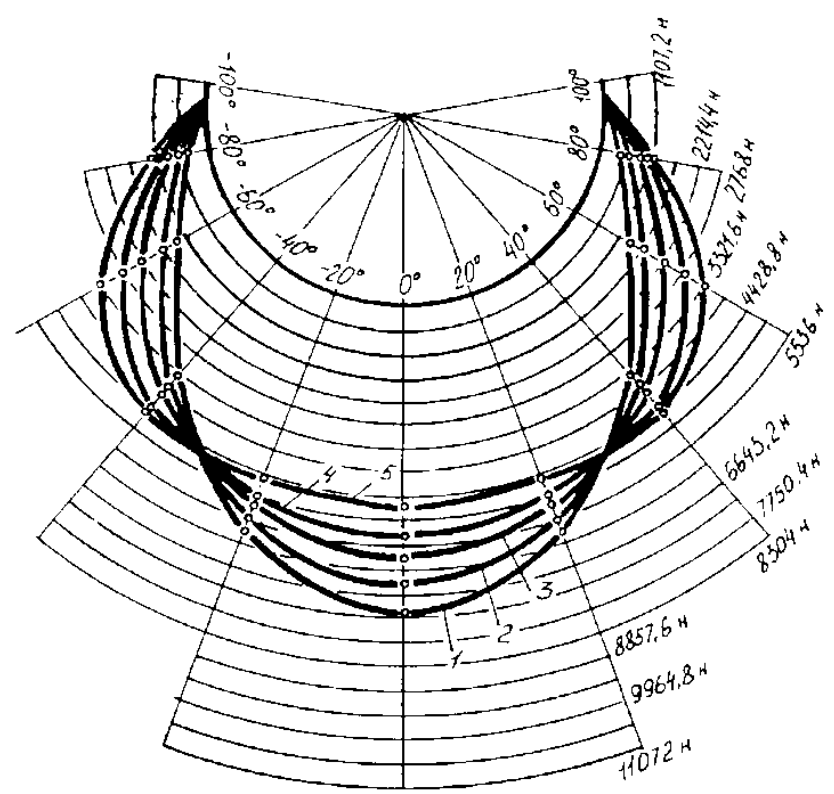

Figure 4. Loading distribution in rolling bearing at its installation on polymer of different thickness: 1 -0,008 mm; 2-0,053 mm; 3-0,098 mm; 4-0,139 mm; $5-0,182 \mathrm{~mm}$.

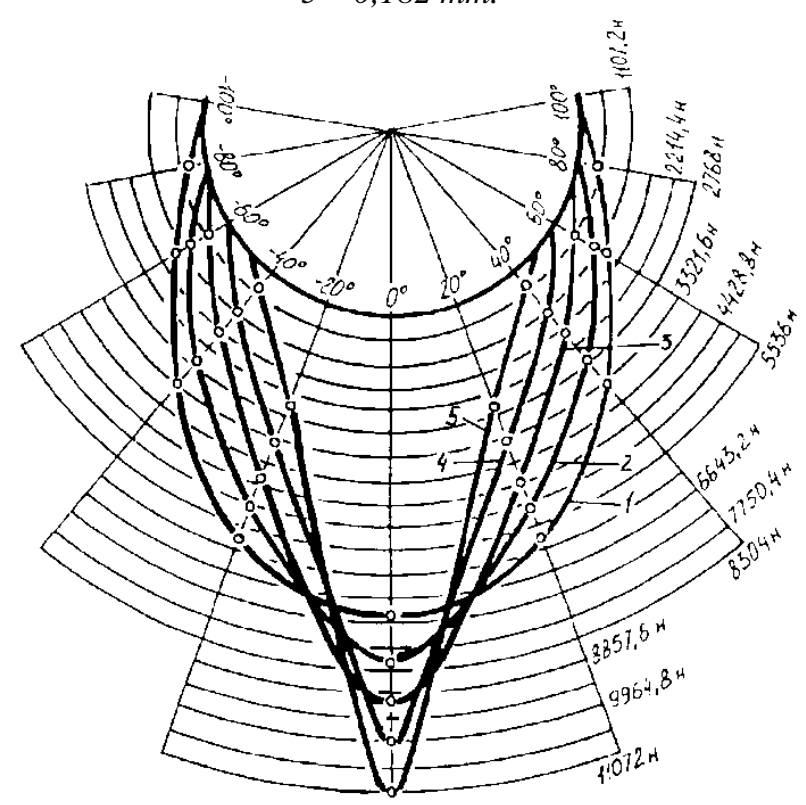

Figure 5. Loading distribution in rolling bearing at its installation without polymer: 1 -tension $0,005 \mathrm{~mm} ; 2$ - clearance $0,057 \mathrm{~mm} ; 3$ - clearance $0,123 \mathrm{~mm}$; 4 - clearance 0,236 $\mathrm{mm} ; 5$ - clearance 0,336 $\mathrm{mm}$. 


\title{
CONCLUSIONS
}

The example cases of adhesive application are demonstration of only some the most frequent defects. In practice the sphere of their application can be considerably broaden. Anaerobic adhesive compositions can be successfully applied by repair and technical enterprises and in some cases, they not only allow substitution of welding, deposition, soldering but restore operating capacity of joints and assemblies, which repair by conventional methods is impossible or problematic. Knowledge of properties and characteristics of adhesive materials allows being aware easily in the sphere of different compositions commercially available, choosing the necessary and applying them in the right way.

\section{REFERENCES}

[1] Ašonja, N.A., Pastuhov, G.A. 2014. Uticaj dijagnostike stanja na pouzdanost dvostr poljoprivrednih kardanskih vratila. Poljoprivredna tehnika, vol. 39, No. 1, p.p. 21-30.

[2] Kravchenko, I., Kuznetsov, Y., Bobryashov, E., Kolomeichenko, A. 2014. Plasma restoration and hardening of elements of tillage tools. Poljoprivredna tehnika, vol. 39, No. 4, pp. 91-99.

[3] Mileusnić, I.Z., Petrović, V.D., Miodragović, M.R., Dimitrijević, Aleksandra. 2010. Uticaj uslova eksploatacije traktora na njegovu pouzdanost i radni vek. Poljoprivredna tehnika, vol. 34, No. 1, pp. 59-67.

[4] Aronovich, D.A., Murokh, A.F., Sineokov, A.P. 2006. Thermal resistant anaerobic sealants and glues. Plastic masses, No. 6, p.p. 37-41.

[5] Ivanov, V.A., Shagunov, D.V., Baikin, S.D. 2012. Modernization of service equipment as a method of enlargement its technological capabilities. Electrotechnical and information complexes and systems, vol. 8, No. 2, pp. 2-8.

[6] Bashkirtsev, Yu.V., Klubnichkin, E.E., Nikishina, O.S. 2011. Utilization of adhesive composition for restoration of transport and technological machine parts of wood enterprises. Bulletin of Moscow State University of Forest - Forest Bulletin, No. 5, pp. 56-62.

[7] Bashkirtsev, Yu.V., Klubnichkin, E.E., Nikishina, O.S. 2011. Utilization of adhesive composition at repair. Agricultural machine operator, No. 3, pp. 34-35.

\section{PRIMENA ANAEROBNIH LEPKOVA KOD POPRAVKI MAŠINA}

\author{
Vladimir Bashkirtsev $^{1}$, Yury Kuznetsov ${ }^{* 2}$, Larisa Kalashnikova ${ }^{3}$ \\ ${ }^{I}$ Ruska inžinjerska akademija za upravljanje i agrobiznis, "Chelyuskinsky", \\ Moskovski region, Ruska fedreracija \\ ${ }^{2}$ Orel državni poljoprivredni Univerzitet, Orel, Ruska federacija \\ ${ }^{3}$ Orel državni poljoprivredni Univerzitet, Orel, Ruska federacija
}

\footnotetext{
* Corresponding author. E-mail: kentury@rambler.ru
} 
Sažetak: Prikazan je značaj primene anaerobnih lepkova tokom održavanja i remonta mašina. Analizirane su komparativne karakteristike anaerobnih kompozita (lepkova) i preporuke o adekvatnom izboru zaštitnog znaka adhezivnog materijala.

Predlažemo konvencionalne tehnologije restauracije radnih kapaciteta spojeva i sklopova koji su izgubili performanse prilikom rada sa anaerobnim lepkom.

Ključne reči: lepak, anaerobni sastav, polimer, popravak, restauracija, hermetizacija, fiksacija, odstojanje.

Prijavljen:

Submitted:

Ispravljen:

Revised:

Prihvaćen:

Accepted:

29. 01. 2018.

12.03.2018

18.03 .2018 